\title{
Natural gas at thermodynamic equilibrium Implications for the
} origin of natural gas

\author{
Frank D Mango*1, Daniel Jarvie ${ }^{2}$ and Eleanor Herriman ${ }^{1}$
}

Address: ${ }^{1}$ Petroleum Habitats, 806 Soboda Ct., Houston, Texas 77079, USA and ${ }^{2}$ Worldwide Geochemistry, 218 Higgins Street, Humble, Texas 77338, USA

Email: Frank D Mango* - dinacat.mango@gmail.com; Daniel Jarvie - danjarvie@wwgeochem.com; Eleanor Herriman - eleanorherriman@gmail.com

* Corresponding author

Published: 16 June 2009

Geochemical Transactions 2009, 10:6 doi:10.1186/1467-4866-10-6
Received: 24 February 2009

Accepted: 16 June 2009

This article is available from: http://www.geochemicaltransactions.com/content/10/1/6

(C) 2009 Mango et al; licensee BioMed Central Ltd.

This is an Open Access article distributed under the terms of the Creative Commons Attribution License (http://creativecommons.org/licenses/by/2.0), which permits unrestricted use, distribution, and reproduction in any medium, provided the original work is properly cited.

\section{Abstract}

It is broadly accepted that so-called 'thermal' gas is the product of thermal cracking, 'primary' thermal gas from kerogen cracking, and 'secondary' thermal gas from oil cracking. Since thermal cracking of hydrocarbons does not generate products at equilibrium and thermal stress should not bring them to equilibrium over geologic time, we would not expect methane, ethane, and propane to be at equilibrium in subsurface deposits. Here we report compelling evidence of natural gas at thermodynamic equilibrium. Molecular compositions are constrained to equilibrium,

$$
\mathrm{K}=\left[\left(\mathrm{CH}_{4}\right)^{*}\left(\mathrm{C}_{3} \mathrm{H}_{8}\right)\right] /\left[\left(\mathrm{C}_{2} \mathrm{H}_{6}\right)^{2}\right]
$$

and isotopic compositions are also under equilibrium constraints:

$$
\begin{aligned}
& \mathrm{K}_{1,2}=\left[\left({ }^{13} \mathrm{C}_{2}\right) *\left({ }^{12} \mathrm{C}_{1}\right)\right] /\left[\left({ }^{13} \mathrm{C}_{1}\right) *\left({ }^{12} \mathrm{C}_{2}\right)\right] \\
& \mathrm{K}_{1,3}=\left[\left({ }^{13} \mathrm{C}_{3}\right) *\left({ }^{12} \mathrm{C}_{1}\right)\right] /\left[\left({ }^{13} \mathrm{C}_{1}\right) *\left({ }^{12} \mathrm{C}_{3}\right)\right]
\end{aligned}
$$

The functions $\left[\left(\mathrm{CH}_{4}\right) *\left(\mathrm{C}_{3} \mathrm{H}_{8}\right)\right]$ and $\left[\left(\mathrm{C}_{2} \mathrm{H}_{6}\right)^{2}\right]$ exhibit a strong nonlinear correlation $\left(\mathrm{R}^{2}=0.84\right)$ in which the quotient $\mathrm{Q}$ progresses to $\mathrm{K}$ as wet gas progresses to dry gas. There are striking similarities between natural gas and catalytic gas generated from marine shales. A Devonian/ Mississippian New Albany shale generates gas with $\mathrm{Q}$ converging on $\mathrm{K}$ over time as wet gas progresses to dry gas at $200^{\circ} \mathrm{C}$.

The position that thermal cracking is the primary source of natural gas is no longer tenable. It is challenged by its inability to explain the composition of natural gas, natural gases at thermodynamic equilibrium, and by the existence of a catalytic path to gas that better explains gas compositions. 


\section{Background}

The hydrocarbons in natural gas are believed to come from two sources, one biological ('biogenic gas'), and the other from thermal cracking, 'primary thermal gas' from kerogen cracking and 'secondary thermal gas' from oil cracking $[1,2]$. Although there is general agreement on the source of biogenic gas, disagreement persists over the origin of thermal gas. One point of controversy is that thermal cracking does not produce a gas resembling natural gas. Oil and kerogen pyrolysis typically give between 10 and $60 \%$ wt methane $\left(\mathrm{C}_{1}-\mathrm{C}_{4}\right)$ [3-9] while natural gas contains between 60 and $95+\%$ methane [10]. None of the explanations that have been offered to explain this [1115] are satisfactory [16]. Catalysis by reduced transition metals can, in theory, explain high-methane in natural gas [17], and this hypothesis is supported by experimental results. Crude oils and $n$-alkanes decomposed over reduced nickel and cobalt oxides produce gas resembling natural gas in molecular and isotopic compositions [18]. There is, however, no evidence of metal activity in sedimentary rocks and therefore no compelling reason to question thermal cracking theory. Moreover, recent hydrous pyrolysis experiments with metal-rich Permian Kupferschiefer shale showed little evidence of catalytic activity, seemingly dismissing the possibility of a catalytic path to natural gas [19].

This changed with the recent disclosure of natural catalytic activity in marine shales at temperatures $300^{\circ}$ below thermal cracking temperatures [20]. Shales generated gas under anoxic gas flow at $50^{\circ} \mathrm{C}$, nearly five times more gas than the same shale would generate at $350^{\circ} \mathrm{C}$ through thermal cracking. Although there was only indirect evidence for transition metals as the active catalysts, it nevertheless established natural catalytic activity in source rocks believed to be major sources of natural gas. There are, therefore, two possible paths to natural gas, a thermogenic path operating almost exclusively at high temperatures, and a catalytic path operating at much lower temperatures. The latter redefines the time-temperature dimensions of gas habitats opening the possibility of gas generation at subsurface temperatures previously thought impossible.

Thermodynamic equilibrium could shed light on which of these paths might dominate in nature. Thermal reactions are generally under kinetic control and their products removed from thermodynamic equilibrium while catalytic reactions are often under equilibrium control and their products near equilibrium. Hydrocarbons can achieve equilibrium through metathesis where homologues interconvert (Reaction 1).

$$
2 \mathrm{C}_{\mathrm{n}} \mathrm{H}_{\mathrm{m}} \rightleftharpoons \mathrm{C}_{\mathrm{n}-1} \mathrm{H}_{\mathrm{m}-2}+\mathrm{C}_{\mathrm{n}+1} \mathrm{H}_{\mathrm{m}+2}
$$

Olefin metathesis $[21,22]$ is a well-known catalytic reaction shown in Reaction 2 for propylene. It is an extraordinary catalytic process because it breaks and makes carboncarbon double bonds and reshuffles olefinic carbons distributing them randomly to new partners. Catalyzed by a variety of transition metals, it proceeds to equilibrium at low temperatures with conservation of $\pi$ and $\sigma$ bonds [23]. Metathesis of methane, ethane, and propane is illustrated in Reaction 3, referred to here as 'gas metathesis'. Although hypothetical, it bears a strong resemblance to olefin metathesis in stoichiometry (1) and to low-temperature gas generation in marine shales [20]. Hydrocarbons decompose over reduced nickel and cobalt oxides to $\mathrm{C}_{1}-\mathrm{C}_{3}$ compositions near equilibrium, possibly through catalytic gas metathesis [18]. Equilibrium between hydrocarbons in natural environments is not limited to metathesis, however. Metastable equilibria have been reported from the interaction of hydrocarbons, water, and authigenic mineral assemblages [24-26].

$$
\begin{array}{r}
2 \mathrm{C}_{3} \mathrm{H}_{6} \rightleftharpoons \mathrm{C}_{2} \mathrm{H}_{4}+\mathrm{C}_{4} \mathrm{H}_{8} \\
2 \mathrm{C}_{2} \mathrm{H}_{6} \rightleftharpoons \mathrm{CH}_{4}+\mathrm{C}_{3} \mathrm{H}_{8}
\end{array}
$$

Gas metathesis without the aid of a catalytic agent is highly unlikely. Hydrocarbon cracking generates methane, ethane, and propane removed from thermodynamic equilibrium $[3,27]$, and their extraordinary thermal stabilities $[28,29]$ preclude equilibrium over geologic time. Thus natural gas at metathetic equilibrium (3) would implicate catalytic assistance.

Here we address metathetic equilibrium in shale gas generation and in natural gas deposits, and discuss the genetic implications.

\section{Results and discussion}

Methane or propane tends to dominate the hydrocarbons emerging from marine shales under anoxic isothermal gas flow [20]. Fig. 1 illustrates two examples, a methane-rich gas from a high-maturity Mississippian Barnett shale (a) and a propane-rich gas from a lower-maturity Devonian/ Mississippian New Albany shale (b).

The possibility that these are preexisting hydrocarbons desorbed under isothermal gas flow is inconsistent with the order in which hydrocarbons are released over time. Desorption under isothermal gas flow is a first order process where light hydrocarbons $\left(C_{x}\right)$ will desorb before heavy hydrocarbons $\left(\mathrm{C}_{\mathrm{y}}\right)$ with concentrations $\left[\mathrm{C}_{\mathrm{x}}\right]$ and $\left[\mathrm{C}_{\mathrm{y}}\right]$ in the effluent gas stream falling exponentially over time [30]. In our analysis of exponential desorption, ratios $\left(\left[\mathrm{C}_{\mathrm{x}}\right] /\left[\mathrm{C}_{\mathrm{y}}\right]\right)$ will also fall exponentially over time irrespective of the concentrations adsorbed on surfaces or 


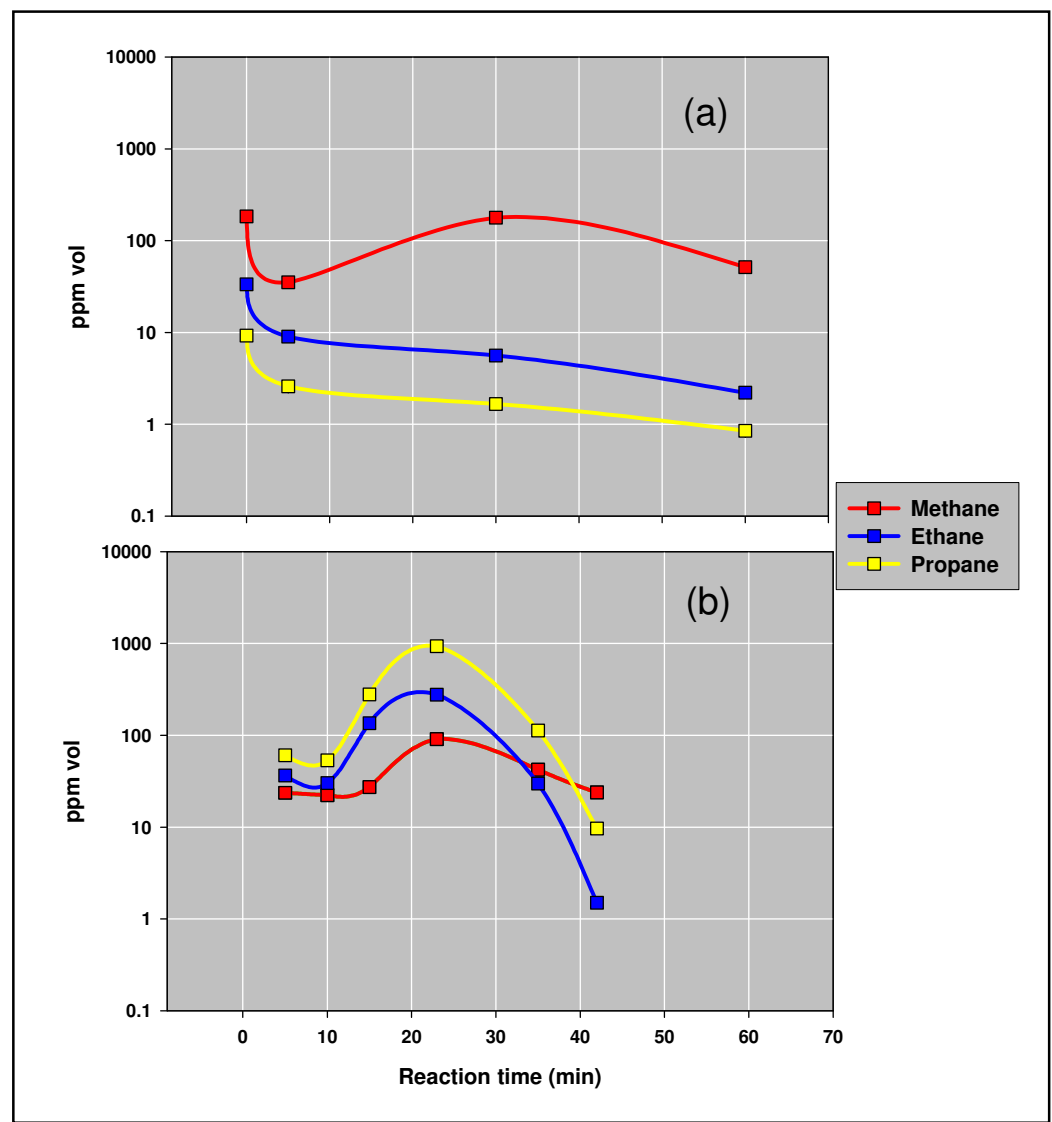

\section{Figure I}

Shale decomposition products under anoxic conditions, $200^{\circ} \mathrm{C}$ isothermal helium flow. The figure shows hydrocarbon concentrations (ppm vol) in the effluent gas coming off the indicated shales over time. The experimental procedure and product analysis are described elsewhere [20]. (a) Barnett Shale is Mississippian from the Delaware Basin, TX (Reeves County, well cuttings, $3500 \mathrm{~m}$ ). Yield $=0.04 \mathrm{mg}$ gas $/ \mathrm{g}$ rock $\left(\mathrm{C}_{1}-\mathrm{C}_{5}\right)$. Rock-Eval: $\mathrm{TOC}=8.1 \% \mathrm{wt} ; \mathrm{SI}=0.95 \mathrm{mg} / \mathrm{g} ; \mathrm{S} 2=\mathrm{I} . \mathrm{I} \mathrm{mg} / \mathrm{g} ; \mathrm{S} 3=$ $0.25 \mathrm{mg} / \mathrm{g}$; Tmax = 548. (b) Upper Dev/L Miss New Albany Shale from the Illinois Basin, KY (side wall core, I025 m). Rock-Eval: $\mathrm{TOC}=6.2 \% \mathrm{wt} ; \mathrm{SI}=2.2 \mathrm{mg} / \mathrm{g} ; \mathrm{S} 2=17 \mathrm{mg} / \mathrm{g} ; \mathrm{S} 3=0.3 \mathrm{mg} / \mathrm{g} ; \mathrm{Tmax}=448$. Yield = $1.2 \mathrm{mg}$ gas $/ \mathrm{g}$ rock $\left(\mathrm{C}_{1}-\mathrm{C}_{5}\right)$.

in solution. Thus, the relative amounts of heavy and light hydrocarbons adsorbed will effect the ratio $\left(\left[\mathrm{C}_{\mathrm{x}}\right] /\left[\mathrm{C}_{\mathrm{y}}\right]\right)$, but not its exponential fall over time with isothermal gas flow. It would not be possible for $\left(\left[\mathrm{C}_{\mathrm{x}}\right] /\left[\mathrm{C}_{\mathrm{y}}\right]\right)$ to remain constant or increase over time, for example.

There is no evidence of desorption in Fig. 1. $\left[\mathrm{C}_{1}\right] /\left[\mathrm{C}_{3}\right]$ in (a) rises from 20 to over 100 in the first 30 minutes of gas flow, then falls to 60 at the end of data collection. The ratio in (b) is nearly constant over 35 minutes of gas flow ( $\sim 0.3$ ), then rises sharply to 2.5 at the end of data collection. The remarkable proportionality between ethane and propane sustained throughout both reactions and its independence of methane concentrations are also inconsistent with desorption. Since desorption under isothermal gas flow should not produce $\left[\mathrm{C}_{2}\right] /\left[\mathrm{C}_{3}\right]$ ratios remaining constant over time and $\left[\mathrm{C}_{1}\right] /\left[\mathrm{C}_{3}\right]$ ratios increasing over time, it must be dismissed as a possible source of the gases produced in these experiments.

The gases are distinct in one other respect. Barnett gas is near thermodynamic equilibrium while New Albany gas is far removed from equilibrium. Equation 4 shows the equilibrium constant $\mathrm{K}$ for methane, ethane, and propane (3) (where $\mathrm{C}_{1}=\mathrm{CH}_{4} ; \mathrm{C}_{2}=\mathrm{C}_{2} \mathrm{H}_{6} ; \mathrm{C}_{3}=\mathrm{C}_{3} \mathrm{H}_{8}$ ).

$$
\mathrm{K}=\left(\mathrm{C}_{1} * \mathrm{C}_{3}\right) /\left(\mathrm{C}_{2}\right)^{2}
$$

Log $\mathrm{K}$ for equilibrium at a reaction temperature of $200^{\circ} \mathrm{C}$ is 0.90 at one atmosphere [31]. The average composition for the gases in Fig. 1 place the quotient $\mathrm{Q}, \mathrm{Q}=\left(\mathrm{C}_{1}{ }^{*} \mathrm{C}_{3}\right) /$ 
$\left(C_{2}\right)^{2}$, at $\log Q=0.40$ for Barnett gas and $\log Q=-1.30$ for New Albany gas, where $\mathrm{C}_{1}, \mathrm{C}_{2}, \& \mathrm{C}_{3}$ are \% vol.

A catalytic reaction can be metathetic, under equilibrium control, and still yield these hydrocarbons removed from equilibrium. All catalytic reactions tend to equilibrium over time in hydrocarbons that interconvert. Product compositions will therefore change over time, removed from equilibrium initially (short residence times), but approaching equilibrium with time. Thus, in flow reactors where residence times are short, gas metathesis could generate these hydrocarbons removed from equilibrium.

The New Albany reaction was repeated under closed conditions for evidence of gas metathesis over longer residence times. Gas flow was continued for 20 minutes to insure active gas generation, then the reactor was closed and its contents allowed to stand for 200 hours at $200^{\circ} \mathrm{C}$.
Fig. 2 shows the changes in gas composition over time and Fig. 3 shows the approach to equilibrium that attends these changes.

The New Albany shale generates gas removed from equilibrium under flow conditions (Fig. 1b) and approaching equilibrium under closed conditions (Fig. 3). Equilibrium over time is a signature of catalysis. In this instance, it progresses to equilibrium and gas dryness in concert (Fig. 2 ). Natural gases might also progress to equilibrium and dryness in concert if the natural process is similarly catalytic.

Two methods were used to approximate the equilibrium constant K (eq. 4) in the subsurface. One approximates Gibbs free energies as a function of temperature and pressure [32] and the other log $\mathrm{K}$ values at various temperatures for ideal gases at one atmosphere [31]. For

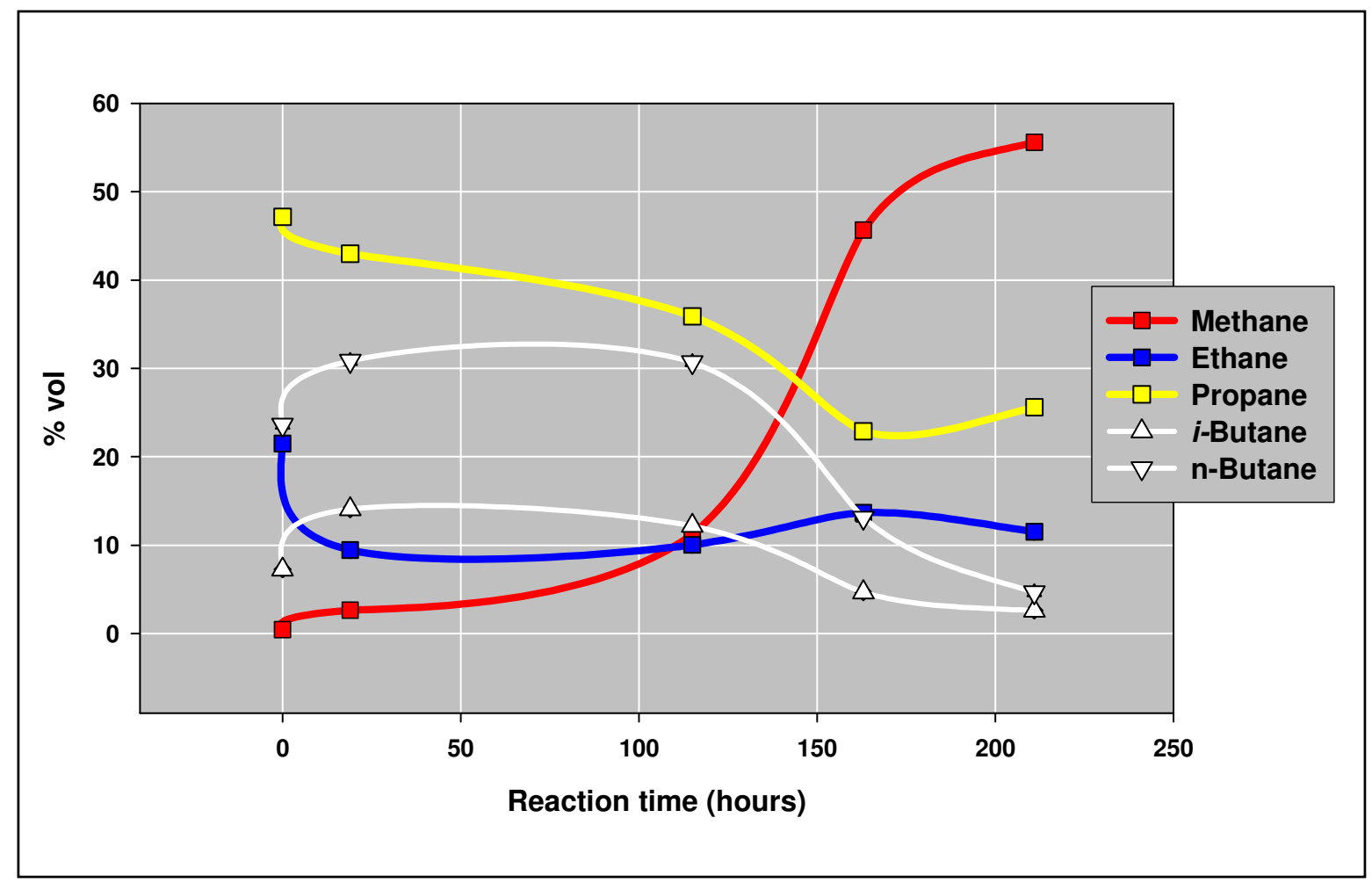

Figure 2

Gas compositions over time, closed reactor, anoxic procedure, New Albany shale (Fig. I), $200^{\circ} \mathrm{C}, \mathrm{Helium}$. After anoxic helium flow for 20 min., the reactor was closed, and the gas was analyzed (GC) at the indicated times by opening the reactor briefly to allow gas from the reactor to pass into a six-way valve for GC analysis [20]. 


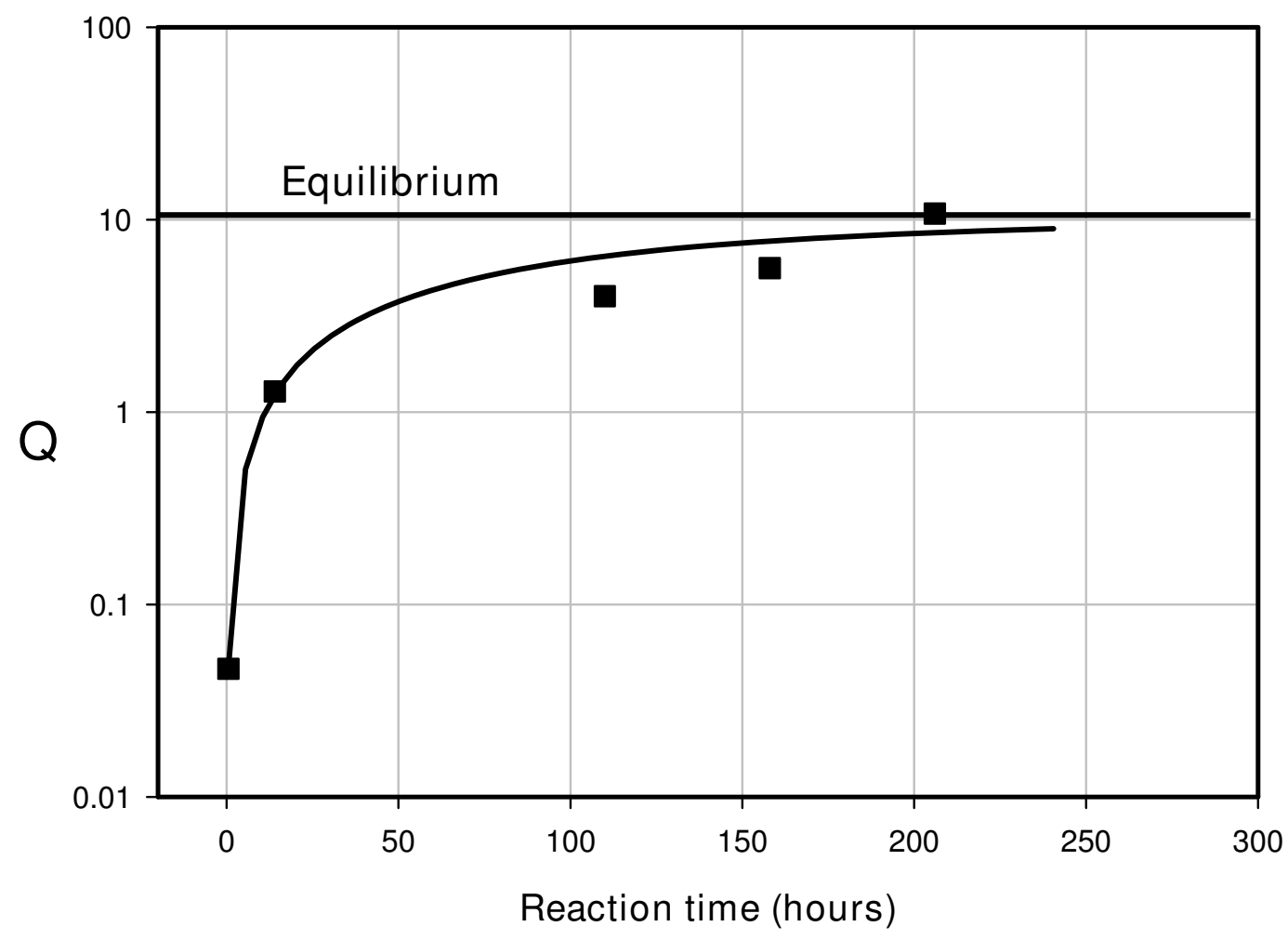

Figure 3

Gas composition over time and thermodynamic equilibrium. Gas compositions are shown in Fig. 2 . $Q$ is the quotient $\left[\left(C_{1}\right)\left(C_{3}\right)\right] /\left[\left(C_{2}\right)^{2}\right]$, where concentrations are \% vol. The horizontal line is the equilibrium constant $K(K=10)$ for the reaction conditions [3I]. The solid line through the data is from the equation $Q(t)=10^{*}\left(I-e^{-\alpha t}\right)$, where $Q(t)$ is the quotient at time $t$ (hours), 10 is $Q$ at infinite time, and the constant $\alpha$ was set to 0.0094 to fit the data.

temperatures between $325 \mathrm{~K}$ and $575 \mathrm{~K}$, and pressures between $3 \mathrm{MPa}$ and $150 \mathrm{MPa}$, log $\mathrm{K}$ falls between 0.9 and 1.3 [32]. The second approximation [31] also places equilibrium limits within the same region: $\log K=0.73$ (575 $\mathrm{K})$ and $1.4(325 \mathrm{~K})$. If natural gas compositions are constrained by equilibrium forces, they should have $\log Q$ values near these limits relative to the $\log \mathrm{Q}$ limits for unaltered thermogenic gases.

Figure 4 is a histogram of $\log \mathrm{Q}$ for offshore Gulf of Mexico gases [33]. These gases were chosen because they are mostly free gases not associated with crude oils or other materials that might compromise their thermodynamic properties. The gases are divided into non-microbial and microbial according to dryness ( $\%$ wt $\mathrm{C}_{1}$ in $\left.\mathrm{C}_{1}-\mathrm{C}_{4}\right)$. The non-microbial gases are largely within the approximated equilibrium limits, while the microbial gases are clearly removed from those limits.

Gas products from thermal cracking experiments fall within the region marked 'Thermal Cracking' in Fig. $4[3,27,34-36]$. We would expect 'primary thermal gas' from kerogen cracking and 'secondary thermal gas' from oil cracking to fall within this region as well. The displacement of natural gases to the right of this region by two log unit is therefore significant.

Figure 5 shows a similar displacement in 1600 gases from various basins in North America.

Figs. 4 \&5 challenge the notion that thermal cracking is the source of natural gas irrespective of thermodynamic equilibrium. How do we explain $\log Q$ values displaced 


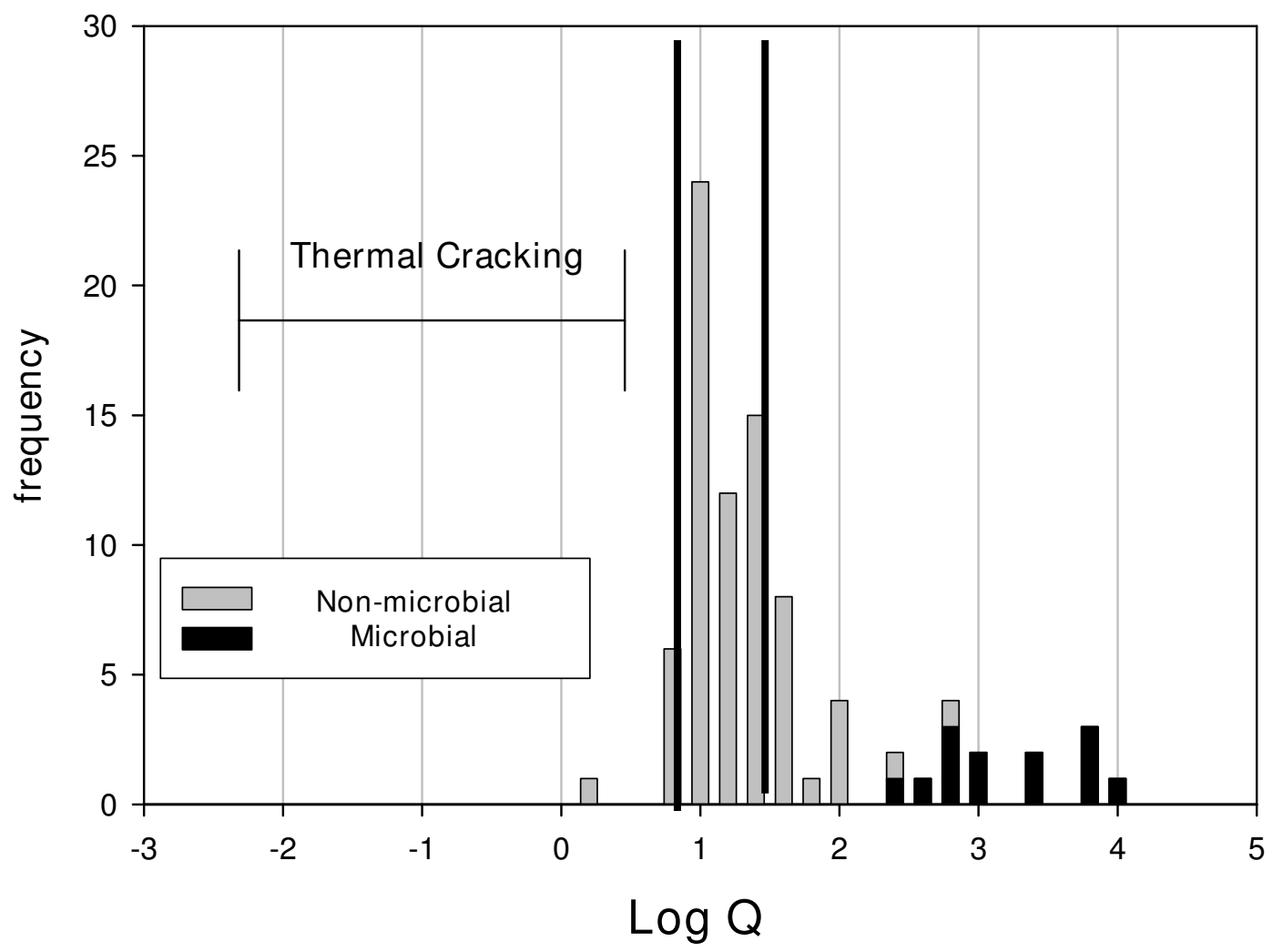

Figure 4

Histogram log Q, 87 Offshore Gulf of Mexico Gases [29]. \% vol was used to calculate $Q$, the quotient $\left[\left(C_{1}\right)\left(C_{3}\right)\right] /\left[\left(C_{2}\right)^{2}\right]$. Microbial gases have \% wt $C_{1}\left(C_{1}-C_{4}\right)>99 \%$ and average log $Q=3.1 \pm 0.53 ; \delta^{13} C_{1}$ average $-61.7 \pm 7.1$, a signature considered biogenic. Only one had $\delta^{13} C_{1}$ below -50 . Non-microbial gases have \% wt $C_{1}\left(C_{1}-C_{4}\right)<99 \%$ and average log $Q=I .2 \pm 0.38$. The dark vertical lines indicate approximate thermodynamic equilibrium limits for subsurface conditions [3I,3I]. The log $Q$ region marked 'Thermal Cracking' represents the products of thermal cracking based on laboratory experiments [3,27,34-36].

from where they should be by two log units? The fact that they are displaced towards thermodynamic equilibrium, in this case metathetic equilibrium, raises the possibility that they were generated catalytically under equilibrium constraints, not thermally under kinetic constraint. It is possible, in other words, that there was no displacement; they were generated where they are.

Figure 6 supports this supposition. It shows a strong correlation between $\left[\left(\mathrm{CH}_{4}\right)^{*}\left(\mathrm{C}_{3} \mathrm{H}_{8}\right)\right]$ and $\left[\left(\mathrm{C}_{2} \mathrm{H}_{6}\right)^{2}\right]$ consistent with gas compositions constrained to equilibrium. It follows a power function (the solid line) rather than a linear function (lines parallel to the dashed line). The ratio $\mathrm{Q}\left(\left[\left(\mathrm{CH}_{4}\right) *\left(\mathrm{C}_{3} \mathrm{H}_{8}\right)\right] /\left[\left(\mathrm{C}_{2} \mathrm{H}_{6}\right)^{2}\right]\right)$ thus varies systematically with concentrations, displaced from equilibrium at high concentrations of $\mathrm{C}_{2}$ and $\mathrm{C}_{3}$ (wet gas) and at equilibrium at low concentrations $\mathrm{C}_{2}$ and $\mathrm{C}_{3}$ (dry gas). Fig. 7 shows the approach to equilibrium with gas dryness. The line through the data is an equilibrium curve for a reversible reaction approaching equilibrium over time $(\mathrm{t})$ : $\mathrm{Q}=$ $\mathrm{K}_{\text {equi }}\left(1-\mathrm{e}^{-\alpha \mathrm{t}}\right)$. Time $(\mathrm{t})$ has been replaced with $\mathrm{C}_{1} /\left(\mathrm{C}_{2}+\mathrm{C}_{3}\right)$ in Fig. 7, consistent with the generally accepted notion that wet gas converts to dry gas over geologic time $[1,2]$.

Isotope ratios $\left({ }^{13} \mathrm{C} /{ }^{12} \mathrm{C}\right)$ in petroleum hydrocarbons are believed to be functions of primary biological inputs and isotope effects in gas generation and decomposition [2]. Isotopic equilibrium is another factor that can alter primary biological isotope ratios. Replacing ${ }^{12} \mathrm{C}$ with ${ }^{13} \mathrm{C}$ lowers the free energy of hydrocarbons because the car- 


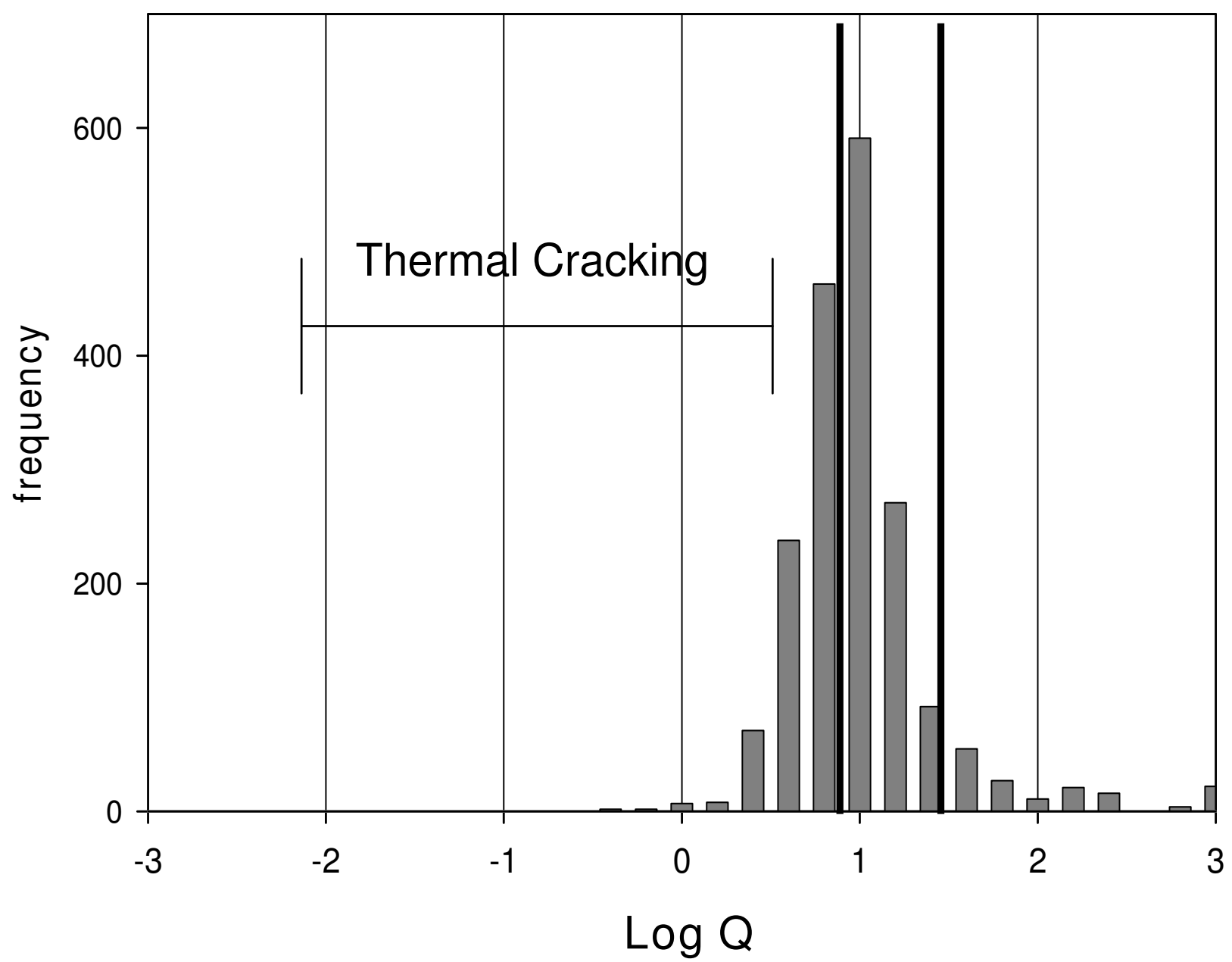

\section{Figure 5}

Natural gas compositions and their relationship to thermodynamic equilibrium. Histogram of log $Q(Q=$ $\left.\left[\left(C_{1}\right) *\left(C_{3}\right) /\left(C_{2}\right)^{2}\right]\right)$ for 1600 gas compositions obtained from the U.S. Department of Interior; mean log $Q=0.90 \pm 0.43$ [I0]. Hydrocarbon concentrations used to calculate log $\mathrm{Q}$ were $\%$ vol $\mathrm{C}_{1}-\mathrm{C}_{5}$. These gases do not include compositions with $\mathrm{C}_{2}$ or $\mathrm{C}_{3}<0.5 \%$ vol. Since concentrations were rounded off to the nearest tenth in the DOI database, values in that range introduced substantial errors in calculating $Q$. The vertical dark lines and the horizontal bar are defined in Fig. 4.

bon and hydrogen bonds to ${ }^{13} \mathrm{C}$ are stronger than the same bonds to ${ }^{12} \mathrm{C}$. Bond energy enhancement increases with carbon number. Replacing ${ }^{12} \mathrm{C}$ with ${ }^{13} \mathrm{C}$ in ethane yields more additional bond energy than it does in methane, for example. Thus, at isotopic equilibrium, ${ }^{13} \mathrm{C}$ will be distributed preferentially in the higher hydrocarbons according to their respective lower free energies [37]. Original ${ }^{13} \mathrm{C}$ input will control the amount of ${ }^{13} \mathrm{C}$ shared between hydrocarbons at equilibrium, but their respective free energies will control how ${ }^{13} \mathrm{C}$ is distributed between them. The distribution of ${ }^{13} \mathrm{C}$ at equilibrium will therefore be independent of original input, rates of gas generation and rates of gas decomposition.
The isotopic equilibrium reaction for methane and ethane is shown in Reaction 5 and for methane and propane in Reaction 6 (the position of ${ }^{13} \mathrm{C}$ in $\mathrm{C}_{3} \mathrm{H}_{8}$ is unspecified).

$$
\begin{gathered}
{ }^{13} \mathrm{CH}_{4}+{ }^{12} \mathrm{C}_{2} \mathrm{H}_{6} \rightleftharpoons{ }^{12} \mathrm{CH}_{4}+{ }^{13} \mathrm{CH}_{6} \\
{ }^{13} \mathrm{CH}_{4}+{ }^{12} \mathrm{C}_{3} \mathrm{H}_{8} \rightleftharpoons{ }^{12} \mathrm{CH}_{4}+{ }^{13} \mathrm{C}^{12} \mathrm{C}_{2} \mathrm{H}_{8}
\end{gathered}
$$

Eqs. 7 and 8 are the isotopic equilibrium equations with $\mathrm{K}_{1,2}$ (7) the carbon isotopic equilibrium constant for methane and ethane, and $\mathrm{K}_{1,3}$ (8) the carbon isotopic equilibrium constant for methane and propane: ${ }^{12} \mathrm{C}_{\mathrm{n}}$ and ${ }^{13} \mathrm{C}_{\mathrm{n}}$ are fugacities; ${ }^{13} \mathrm{C}_{2}={ }^{13} \mathrm{C}^{12} \mathrm{CH}_{6}$, and ${ }^{13} \mathrm{C}_{3}={ }^{13} \mathrm{C}^{12} \mathrm{C}_{2} \mathrm{H}_{8}$. 


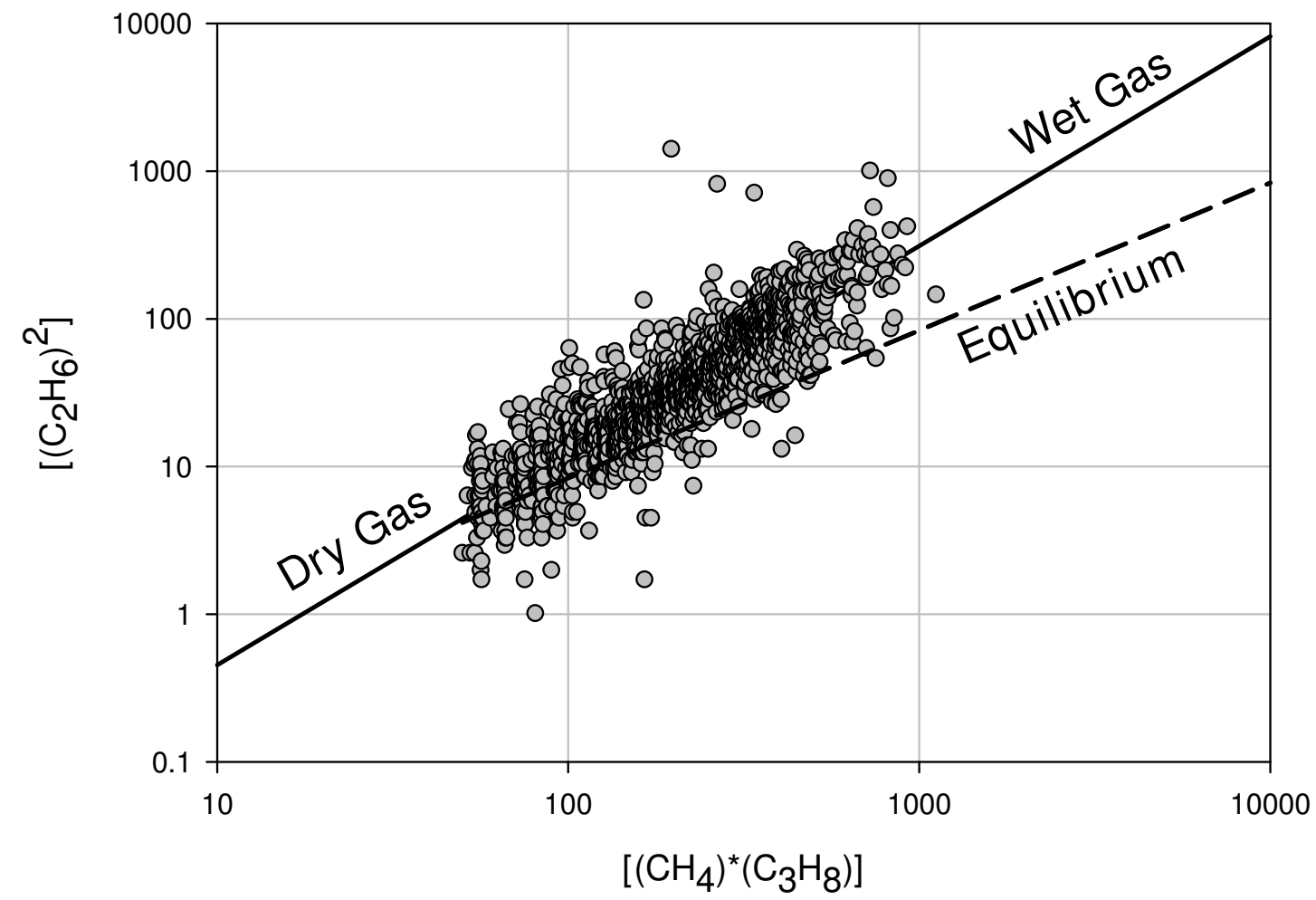

Figure 6

Equilibrium plot of $C_{1}-C_{3}$ (eq. I) in 1600 natural gases (Fig. 5). Hydrocarbon concentrations are \% vol in $C_{1}-C_{5}$. These gases do not include compositions with $\mathrm{C}_{2}$ or $\mathrm{C}_{3}<0.5 \%$ vol since the data, rounded off to the nearest tenth \%, injects unacceptable error into the $\mathrm{x}$ and $\mathrm{y}$ functions. The dark line through the data is the regression line for the power equation $\mathrm{y}=$ $0.0282 x^{1.308}$, where $y=\left(\mathrm{C}_{2} \mathrm{H}_{6}\right)^{2}, x=\left(\mathrm{CH}_{4}\right)^{*}\left(\mathrm{C}_{3} \mathrm{H}_{8}\right)$, and $\mathrm{R}^{2}=0.840$. The dashed line is for $x / y=12.0$, thermodynamic equilibrium at $400 \mathrm{~K}$ [3I]. Gas compositions were obtained from the U.S. Department of Interior [I0]. The mean log $Q(Q=(x / y)$ for the data $=0.90 \pm 0.43$.

$$
\begin{aligned}
& \left({ }^{13} \mathrm{C}_{2}\right) *\left({ }^{12} \mathrm{C}_{2}\right)=\mathrm{K}_{1,2}\left({ }^{13} \mathrm{C}_{1}\right) *\left({ }^{12} \mathrm{C}_{2}\right) \\
& \left({ }^{13} \mathrm{C}_{3}\right) *\left({ }^{12} \mathrm{C}_{1}\right)=\mathrm{K}_{1,3}\left({ }^{13} \mathrm{C}_{1}\right) *\left({ }^{12} \mathrm{C}_{3}\right)
\end{aligned}
$$

Table 1 shows the molar isotope ratios and the quotients Q for methane, ethane, and propane in 285 natural gases and it includes data for catalytic gases [18] for comparison, to be discussed below. The quotients $\mathrm{Q}_{1,2}$ and $\mathrm{Q}_{1,3}$ are very close to theoretical equilibrium values at $400 \mathrm{~K}: \mathrm{K}_{1,2}$ $=2.039 ; \mathrm{K}_{1,3}=3.101$ [37]. All ratios show substantial invariance. The variance in $\mathrm{Q}_{1,2}$ and $\mathrm{Q}_{1,3}$ is one half that in the molar isotope ratios within them reflecting the correlations between molar isotope ratios shown in Fig. 8 . Table 1 also displays the extraordinary match between catalytic gases and natural gases.

Fig. 9 shows the proximities of natural gases and catalytic gases to isotopic thermodynamic equilibrium on a $\log \mathrm{K}$ scale.

The approach to equilibrium with dryness (Figs. 6 \& 7 ) mirrors the experimental results shown in Figs. $2 \& 3$. The isotopic results (Figs. 8 \&9) reinforce the position that 


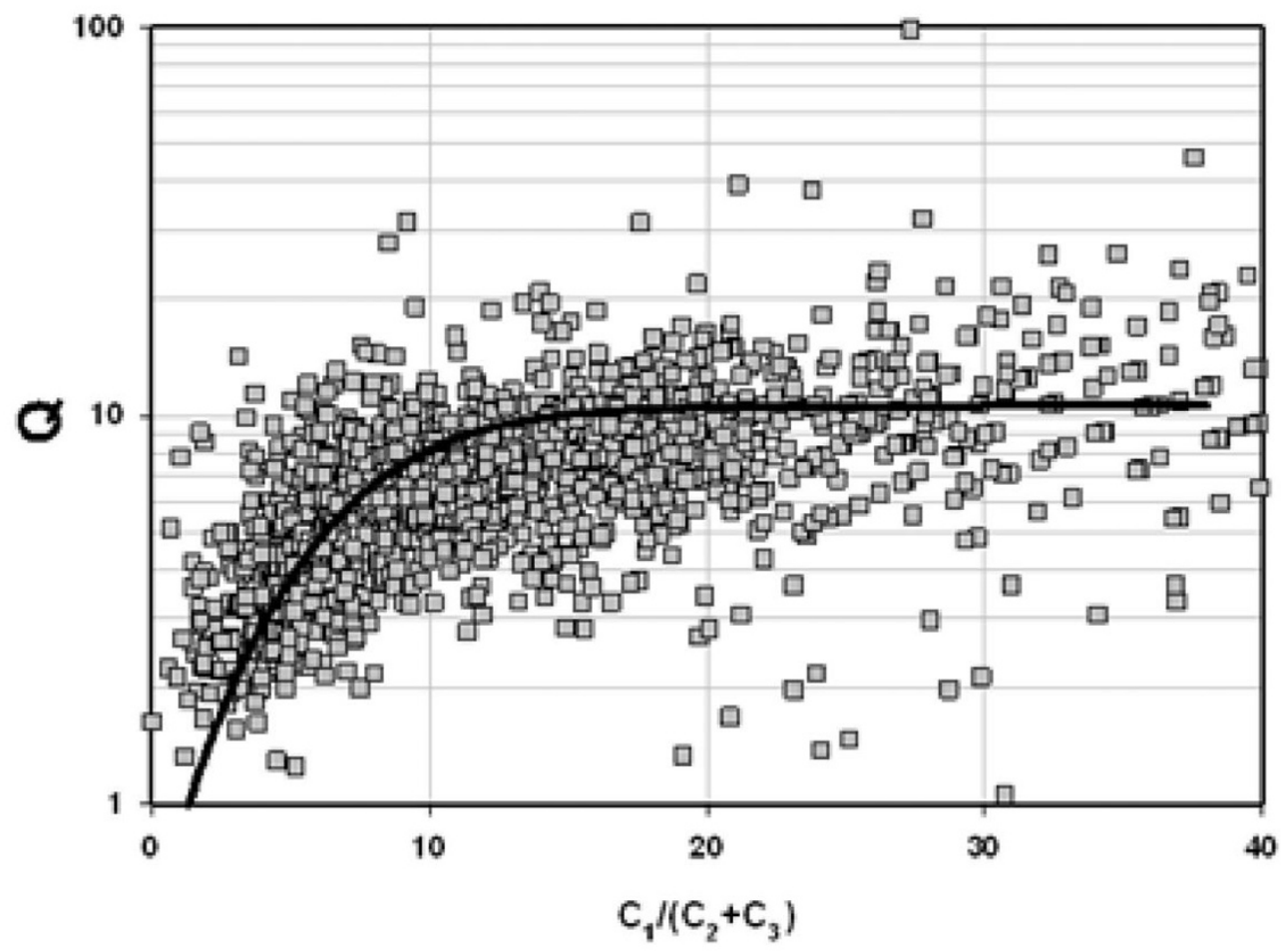

Figure 7

Thermodynamic equilibrium and gas dryness. $Q=\left(C_{1}\right) *\left(C_{3}\right) /\left(C_{2}\right)^{2}$. The data is taken from Fig. 6. The black line passing through the data is the equilibrium curve, where $Q$ approaches the equilibrium constant $K(I 0.4)$ with gas dryness: $Q=I 0.4(I-$ $\left.\mathrm{e}^{-\alpha(C l / C 2+C 3))}\right), \alpha$ was set to 0.1 to fit the data.

hydrocarbons in natural gas are generated under equilibrium constraints. It is a metathetic equilibrium and therefore a catalytic equilibrium.

Other explanations are less satisfactory. It is difficult to explain dry gas generation through thermal cracking $[28,29]$ and harder to explain gas metathesis through thermal stress. Equilibrium requires the facile exchange of carbon atoms between methane, ethane, and propane. Carbon-carbon and carbon-hydrogen $\sigma$ bonds are broken and reformed with overall bond conservation. This is unprecedented in thermal hydrocarbon reactions and inconceivable without catalytic assistance.

\section{Conclusion}

The following results support our position that natural gases are at or near thermodynamic equilibrium:

1) Gas compositions are significantly displaced from thermogenic compositions to equilibrium compositions (Figs. 5 \&6).

2) There is a strong nonlinear correlation between $\left.\left[\left(\mathrm{C}_{1}\right)^{*} \mathrm{C}_{3}\right)\right]$ and $\left[\left(\mathrm{C}_{2}\right)^{2}\right]$ in which the quotient $\mathrm{Q}$ converges on equilibrium as wet gas progresses to dry gas (Figs. 6) consistent with an approach to equilibrium over geologic time (Fig. 7). 


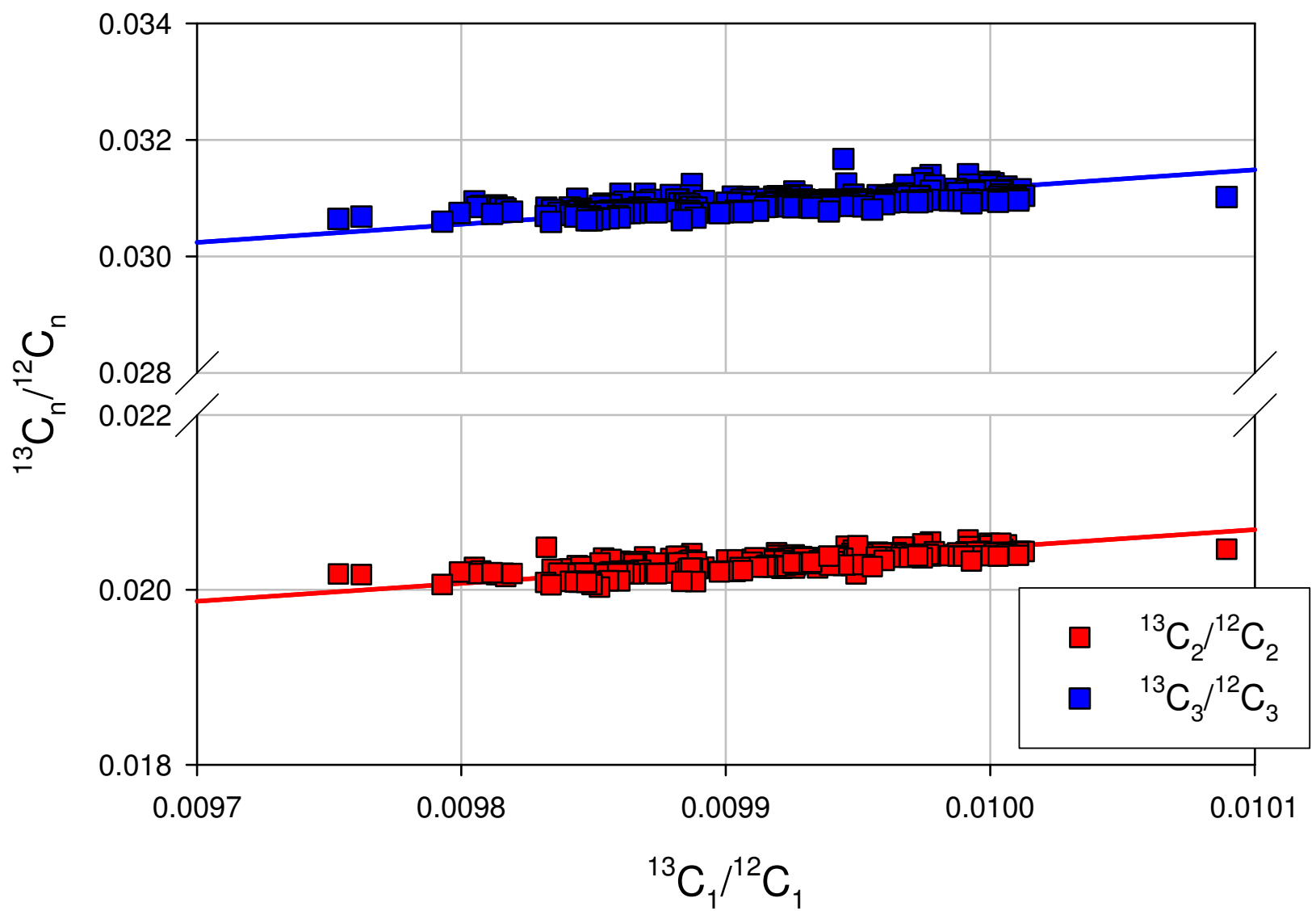

Figure 8

The correlations between molar isotope ratios in methane, ethane, and propane in 285 gases (USGS, Table I). Ratios are molar, calculated as described in Table I. The lines are linear regression lines with a coefficients of correlation $\mathrm{R}^{2}=$ 0.638 for ${ }^{13} C_{2} / 12 C_{2}$ with slope (zero intercept) $=2.028$, and $R^{2}=0.47$ for ${ }^{13} C_{3} / 12 C_{3}$ with slope (zero intercept) $=3.055$.

Table I: Statistical properties of molar isotope ratios and isotopic equilibrium constants in 285 natural gases and 5 catalytic gases.

\begin{tabular}{|c|c|c|c|c|c|c|}
\hline & \multicolumn{3}{|c|}{ Natural Gases } & \multicolumn{3}{|c|}{ Catalytic Gases } \\
\hline & mean & sd $\times 10^{4}$ & $V \times 10^{6}$ & Mean & sd $\times 10^{4}$ & $v \times 10^{7}$ \\
\hline${ }^{13} C_{1} / 12 C_{1}$ & 0.00991 & 0.55 & 5.8 & 0.00991 & 0.40 & 0.30 \\
\hline${ }^{13} C_{2} / 12 C_{2}$ & 0.02031 & 1.07 & 5.2 & 0.02030 & 0.63 & 1.78 \\
\hline${ }^{13} C_{3} / 12 C_{3}$ & 0.03090 & 1.50 & 4.4 & 0.03090 & 0.97 & 1.9 \\
\hline $\mathbf{Q}_{1,2}$ & 2.0486 & 70.6 & 2.2 & $2.048 I$ & 35.7 & 5.7 \\
\hline $\mathbf{Q}_{1,3}$ & 3.1175 & 130 & 3.3 & 3.1172 & 30.6 & 1.8 \\
\hline
\end{tabular}

Natural gas data was taken from USGS Energy Resource Organic Geochemistry Data Base, http://energy.cr.usgs.gov/prov/og/. Catalytic gases are from octadecene decomposition over reduced nickel oxide $\left(180-210^{\circ} \mathrm{C}\right)$ [18]. $\mathrm{C}_{1}-\mathrm{C}_{3}$ compositions were normalized to $\%$ wt carbon. $\delta^{13} \mathrm{C}$ values were converted to mass ratios which were used to calculate wt ${ }^{13} \mathrm{C}$ at each carbon number: $x_{1}$ at $C_{1}, x_{2}$ at $C_{2}$, and $x_{3}$ at $C_{3}$. Wt ${ }^{13} C_{1}=x_{1} ; W_{t}{ }^{13} C_{2}$ is wt $C_{2}$ with composition ${ }^{13} \mathrm{C}^{12} \mathrm{C}=\mathrm{x}_{2}+\left((12 / 13.00335) \mathrm{x}_{2}\right)$; wt ${ }^{13} \mathrm{C}_{3}$ is wt $\mathrm{C}_{3}$ with composition ${ }^{13} \mathrm{C}^{12} \mathrm{C}_{2}=\mathrm{x}_{3}+\left((24 / 13.00335) \mathrm{x}_{3}\right)$. Wt ${ }^{12} \mathrm{C}$ at $\mathrm{C}_{2}$ was calculated as the total wt ${ }^{12} \mathrm{C}$ at $\mathrm{C}_{2}$ minus the wt ${ }^{12} \mathrm{C}$ in ${ }^{13} \mathrm{C}_{2}$. Wt ${ }^{12} \mathrm{C}$ at $\mathrm{C}_{3}$ was also the total wt ${ }^{12} \mathrm{C}$ at $\mathrm{C}_{3}$ minus the wt ${ }^{12} \mathrm{C}$ in ${ }^{13} \mathrm{C}_{3}$. Weights (per $100 \mathrm{~g})$ were converted to moles/(100 g $\left.\mathrm{C}_{1}-\mathrm{C}_{3}\right)$ which were used throughout our analysis. The quotient $\mathrm{Q}_{1,2}=\left({ }^{13} \mathrm{C}_{2}\right) *\left({ }^{12} \mathrm{C}_{1}\right) /\left({ }^{13} \mathrm{C}_{1}\right) *\left({ }^{12} \mathrm{C}_{2}\right)$ and $\mathrm{Q}_{1,3}$ $=\left({ }^{13} C_{3}\right) *\left({ }^{12} C_{1}\right) /\left({ }^{13} C_{1}\right) *\left({ }^{12} C_{3}\right)$, where concentrations are moles $/ 100$ g. Variance $(v)$ is $(s d)^{2}$ for log (ratio). 


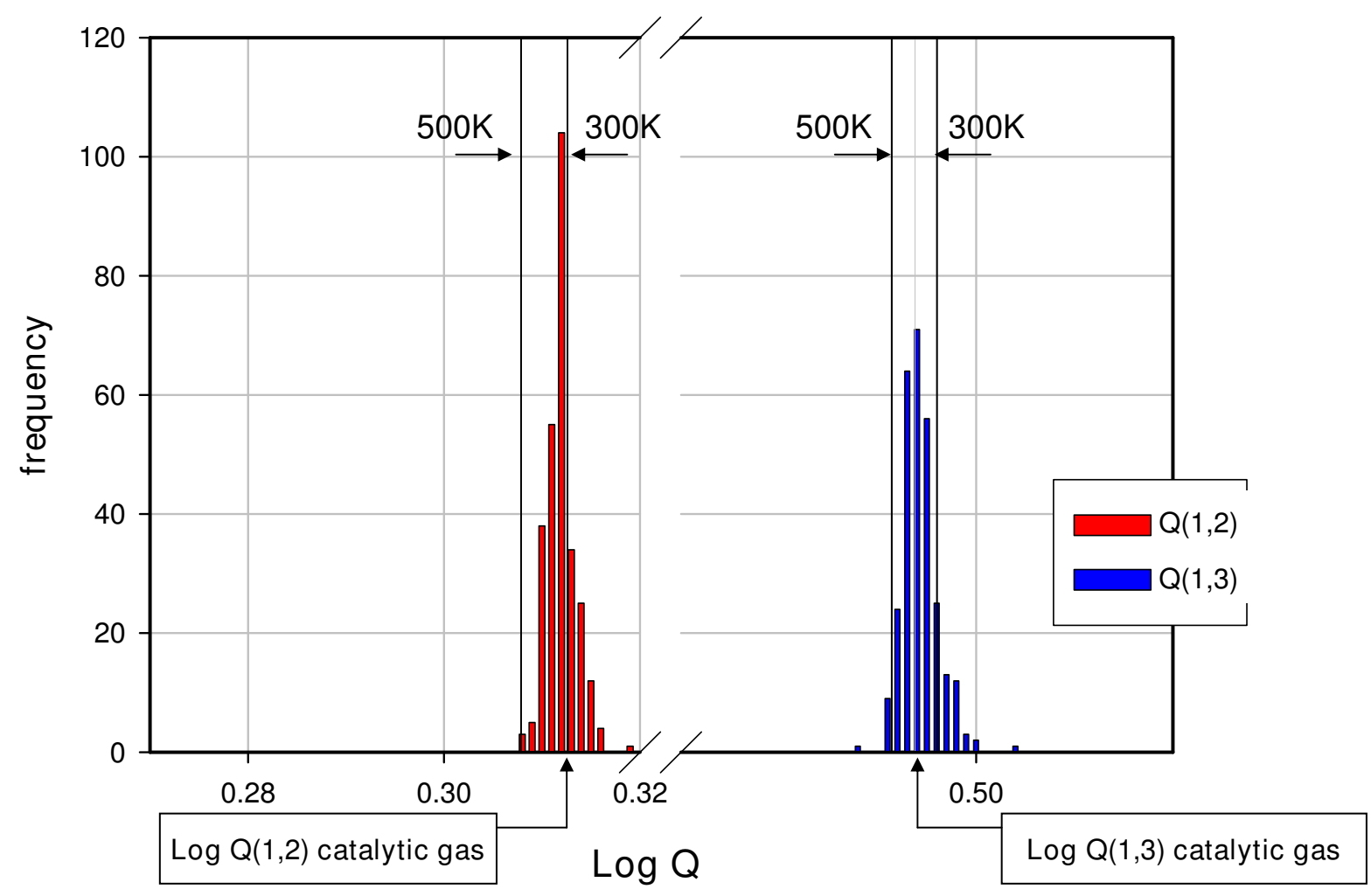

\section{Figure 9}

Histogram of isotopic quotients $\left(\log Q_{1,2}\right.$ and $\log Q_{1,3}$ ) for 285 natural gases (Table $I$ ). All values of $Q_{1,2}$ and $Q_{1,3}$ were calculated as described in Table 1 . The arrows beneath the chart (catalytic gas) mark the positions of $\log Q_{1,2}$ and $\log Q_{1,3}$ for Catalytic Gases in Table I. The vertical lines mark isotopic equilibrium constants at $300 \mathrm{~K}, \log \mathrm{K}_{\mathrm{I}, 2}=0.31259 ; \log \mathrm{K}_{\mathrm{I}, 3}=$ 0.49602 , and at $500 \mathrm{~K}, \log \mathrm{K}_{\mathrm{I}, 2}=0.30786 ; \log \mathrm{K}_{\mathrm{I}, 3}=0.49142$ [37].

3) The isotopic compositions of methane, ethane, and propane are also constrained to equilibrium compositions (Figs 8 \&9).

We propose catalytic gas metathesis as the source of equilibrium in natural gas. The natural catalytic activity in marine shales [20], or some similar activity in other sedimentary rocks, is probably the source of equilibrium in natural gas deposits. This view is supported by the New Albany shale experiment in which Q progressed to metathetic equilibrium over time as wet gas progressed to dry gas (Figs. 2 \&3). A mechanistic connection between degradation to methane [20] and metathesis is suggested.

Catalysis by low valent transition metals [16-18] may be the source of gas metathesis and degradation in the origin of natural gas. The match in isotope ratios between cata- lytic gases and natural gases (Table 1) supports this position and the sensitivity of marine shales to oxygen poisoning [20] supports it as well.

The position that thermal cracking adequately explains the origin of natural gas $[1,2]$ is no longer tenable. It cannot explain the high concentrations of methane in natural gas [16], the distribution of light hydrocarbons $[38,39]$, and the associations with thermodynamic equilibrium reported here. Of the two possible pathways to natural gas, the catalytic path [20] appears the more attractive. It is simple, economic, and does not suffer the now mounting deficiencies challenging thermal cracking theory.

\section{Competing interests}

The authors declare that they have no competing interests. 


\section{Authors' contributions}

FDM formulated theory, experimental design and supervised the experimental work. DJ contributed to the experimental work and helped in shaping the paper. EH was instrumental in early strategy and in writing the ms.

\section{Acknowledgements}

We thank Stephen Garcia for experimental assistance.

\section{References}

I. Tissot BP, Welte DH: Petroleum Formation and Occurrence Springer, New York; 1984.

2. Hunt JM: Petroleum Geochemistry and Geology Freeman, New York; 1995.

3. Voge $\mathrm{HH}$, Good GM: Thermal cracking of higher paraffins. Journal American Chemical Society 1949, 71:593-597.

4. McNab JG, Smith PV, Betts RI: The evolution of petroleum. Petroleum and Engineering Chemistry 1952, 44:2556-2563.

5. Evans RJ, Felbeck GT: High temperature simulation of petroleum formation I. The pyrolysis of Green River Shale. Organic Geochemistry 1983, 4:135-144.

6. Saxby JD, Riley KW: Petroleum generation by laboratory-scale pyrolysis over six years simulating conditions in a subsiding basin. Nature 1984, 308: 175-177.

7. Espitalie J, Ungerer P, Irwin I, Marquis F: Primary cracking of kerogens. Experimenting and modeling $\mathrm{Cl}, \mathrm{C2}-\mathrm{C5}, \mathrm{C} 6-\mathrm{Cl}$, and CI5+ classes of hydrocarbons formed. Organic Geochemistry 1987, 1 3:893-899.

8. Hikita T, Takahashi I, Yoshimichi T: Hydropyrolysis of heavy oils. Fuel 1989, 68: I |40-I| 44.

9. Horsfield B, Schenk HJ, Mills N, Welte DH: An investigation of the in-reservoir conversion of oil to gas: compositional and kinetic findings from closed-system programmed-temperature pyrolysis. Organic Geochemistry 1992, 19:19|-204.

10. Mango FD: The light hydrocarbons in petroleum: a critical review. Organic Geochemistry 1997, 26:417-440.

II. Price LC, Schoell M: Constraints on the origins of hydrocarbon gas from compositions of gases at their site of origin. Nature 1995, 378:368-37I.

12. McNeil RI, BeMent WO: Thermal stability of hydrocarbons: Laboratory criteria and field examples. Energy and Fuels 1996, 10:60-67.

13. van Aarssen DGK, Bastow TP, Alexander R, Kagi RI: Distribution of methylated naphthalenes in crude oils: indicators of maturity, biodegradation and mixing. Organic Geochemistry 1999, 30:1213-1227.

14. Inan S: Gaseous hydrocarbons generated during pyrolysis of petroleum source rocks using unconventional grain size. Organic Geochemistry 2000, 3 I:1409-I4I8.

15. Snowdon LR: Natural gas composition in the geological environment and the implications for the processes of generation and preservation. Organic Geochemistry 200I, 32:913-93I.

16. Mango FD: Methane concentrations in natural gas: the genetic implications. Organic Geochemistry 200I, 32: I283-I 287.

17. Mango FD: Transition metal catalysis in the generation of petroleum and natural gas. Geochimica et Cosmochimica Acta 1992, 56:553-555.

18. Mango FD, Elrod LW: The carbon isotopic composition of catalytic gas: A comparative analysis with natural gas. Geochimica et Cosmochimica Acta 1999, 63:1097-1106.

19. Lewan MD, Kotarba MJ, Wieclaw D, Piestrzynski A: Evaluating transition-metal catalysis in gas generation from the Permian Kupferschiefer by hydrous pyrolysis. Geochimica et Cosmochimica Acta 2008, 72:4069-4093.

20. Mango FD, Jarvie DM: Low temperature gas from marine shales. Geochemical Transactions 2009, 10:3.

21. Cotton FA, Wilkinson G, Murillo CA, Bochmann M: Advanced Inorganic Chemistry 6th edition. John Wiley \& Sons, NY; 1999:I 282-I 285.

22. Rouhi AM: Olefin metathesis: Big-deal reaction. Chemical and Engineering News 2002, 80(5I):29-83.

23. Mango FD: Olefin Metathesis. Coordination Chemistry Reviews 1975, 15:152-163.
24. Fabuss BM, Smith JO, Lait RI, Borsanyi AS, Satterfield CN: Rapid thermal cracking of $\mathbf{n}$-hexadecane at elevated temperatures. Industrial and Engineering Chemistry, Product Develoment 1962, I:293-299.

25. Helgeson HC, Knox AM, Owens CE, Shock El: Petroleum oil field waters, and authigenic mineral assemblages: Are they in metastable equilibrium in hydrocarbon reservoirs. Geochimica Cosmochimica Acta 1993, 57:3295-3339.

26. Seewald JS: Evidence for metastable equilibrium between hydrocarbons under hydrothermal conditions. Nature 1994, 370:285-287.

27. Seewald JS: Organic-Inorganic interactions in petroleum-producing sedimentary basins. Nature 2003, 426:323-333.

28. Laidler KJ, Wojciechowske BW: Kinetics and mechanisms of the thermal decomposition of ethane. I. The uninhibited reaction. Proceedings Royal Society 1961, A260:91-102.

29. Laidler KJ, Sagert NH, Wojciechowske BW: Kinetics and mechanisms of the thermal decomposition of propane. Proceedings Royal Society 1962, A270:242-253.

30. Tokoro Y, Misono M, Uchijima T, Yoneda Y: Analysis of thermal desorption curves for heterogeneous surfaces. I. A linear variation of the activation energy of desorption. Bulletin of the Chemical Society of Japan 1978, 5 I:85-89.

31. Stull DR, Westrum EF Jr, Sinke GC: The chemical thermodynamics of organic compounds Johy Wiley \& Sons, New York; 1969.

32. Lemmon EW, Huber ML, McLinden MO: NIST Standard Reference Database 23: Reference Fluid Thermodynamic and Transport Properties - REFPROP 8.0. National Institute of Standards and Technology, Standard Reference Data Program, Gaithersburg, Maryland 20899, USA; 2007.

33. Rice DD, Threlkeld $C N$ : Natural gas analyses from Offshore Gulf of Mexico. From Gulf Coast Oils and Gases, Their Characteristics, Origin, Distribution, and Exploration and Production Significance. Edited by: Schumacher D, Perkins BF. Proceeding of the Ninth Annual Research Conference, Gulf Coast Section Society of Economic Paleontologists and Mineralologists Foundations; 1990.

34. Behar F, Ungerer P, Kressmann S, Rudkiewiez JL: Thermal evolution of crude oils in sedimentary basins: experimental simulation in a confined system and kinetic modeling. Revue de I'Institut Francais du Pétrole 199I, 46:15I-18I.

35. Horsfield B, Schenk HJ, Mills N, Welte DH: An investigation of the in-reservoir conversion of oil to gas: compositional and kinetic findings from closed-system programmed-temperature pyrolysis. Organic Geochemistry 1992, 19:19|-204.

36. Burkle-Vitzum $\vee$, et al.: Kinetics of alkyl aromatics on the thermal stability of hydrocarbons under geologic conditions. Organic Geochemistry 2004, 35:3-33.

37. Galimov EM, Ivlev AA: Thermodynamic isotope effects in organic compounds. I. Carbon isotope effects in straightchain alkanes. Russian Journal of Physical Chemistry 1973, 47:1564-66.

38. Mango FD: An invariance in the isoheptanes of petroleum. Science 1987, 237:5।4-517.

39. Mango FD: The stability of hydrocarbons under the time-temperature conditions of petroleum genesis. Nature 1991, 352:146-148.

Publish with Bio Med Central and every scientist can read your work free of charge

"BioMed Central will be the most significant development for disseminating the results of biomedical research in our lifetime. "

Sir Paul Nurse, Cancer Research UK

Your research papers will be:

- available free of charge to the entire biomedical community

- peer reviewed and published immediately upon acceptance

- cited in PubMed and archived on PubMed Central

- yours - you keep the copyright 